\title{
Effect of different constant and alternative temperatures and light situations on germination behavior of two Purslane (Protulaca oleracea L.) populations
}

\author{
Golzardi $\mathrm{F}^{1^{*}}$, Vaziritabar $\mathrm{Y}^{2}$,Vaziritabar $\mathrm{Y}^{2}$, Sadat Asilan $\mathrm{K}^{3}$,Ashraf $\mathrm{M}^{3}$, Ebadi SZ ${ }^{4}$, \\ Sarvaramini $\mathrm{SH}^{5}$
}

${ }^{1}$ Seed Plant Improvement Institute, Karaj, Iran; ${ }^{2}$ Department of Agronomy, Science and Research Branch of Tehran, Islamic Azad University, Tehran, Iran; ${ }^{3}$ Department of Agricultural Sciences (Agronomy Engineering), Payame Noor University (PNU), Iran; ${ }^{4}$ Department of Agronomy, Karaj Branch, Islamic Azad University, Karaj, Iran; ${ }^{5}$ Department of Agricultural Management and Development, University of Tehran, Karaj, Iran.

[Received: July 22, Accepted: September 19, 2014]

\begin{abstract}
This study was carried out to investigate the germination behavior of two purslane populations (Karaj and Ahvaz), the effect of constant temperatures under two light regimes (12 hrs light/dark and continuous dark), alternative temperatures (day/night) and the lighting/darkness periods on purslane germination. The study was conducted in a randomized complete blocks design with four replications. The results showed that the highest percentage and germination rate in constant temperatures under two light regimes in Karaj mass (continuous darkness) and Ahvaz (12/12 hrs light/darkness), respectively at 25 and $30{ }^{\circ} \mathrm{C}$ (Optimum temperature) was observed. Purslane percentage and germination rate changes in alternating temperature (day/night) showed, the maximum values of both masses achieved at $30 / 20^{\circ} \mathrm{C}$ alternative temperature. According to result, by getting away from the optimum temperature, the germination percentage and its rate tends to have a descending process in both thermal experiments (alternative and constant temperature tests). Also the effect of different darkness/light periods on purslane percentage and germination rate showed, at (0/24) constant darkness treatment these traits got to the lowest point. The highest percentage and germination rates in Karaj and Ahvaz populations, respectively observed at 0/24, 12/12, 10/14 and 8/16 treatments; which had no statistical difference. Radicle length, shoot length and fresh weight of seedlings in both populations at constant temperatures under both light regimes at 20 to $30^{\circ} \mathrm{C}$ and alternative temperatures (light/dark) at $30 / 20^{\circ} \mathrm{C}$ had the highest values. Key words: Purslane, Germination, Constant temperatures, alternating temperatures.
\end{abstract}

\section{INTRODUCTION}

Purslane is an annual weed from Portulacaceae family, which develops appropriately in the warm and drought situations. Dominantly it generates with seed, but if the soil humidity be well, it can spread by stalk fragments. Purslane is able to develop in a different regional situations and extent ranges of the soil condition. The succulent traits of purslane made it able to be alive when it lost its roots; even it can complete its productive growth to generate seeds. Hence, controlling and abolishing of purslane is so exhausting [1].

Seed germination is the main factor to thrive weed in the ecological niche, because it is the initial stage for weeds competition [2]. Furthermore seedling establishment is the sensitive point in plants life cycle and the first stage of this cycle is germination, which has determinant role on seedling establishment and development in ecosystem [3, 4]. Germination is the consequence of complex interactions between some interior and exterior factors [5]. Weeds germination associated to different factors like soil circumstances, regional and physiological situation; but there are immense reports which emphasized on different temperature and light situation effects on weeds germination [6, $7 \& 8]$. To improve the agriculture management systems, recognizing the seed dormant characteristics, germination patterns and seeds alternation between weeds population is so crucial.
The germination of 42 weed species under different lightning/darkness patterns showed that 26 species of total population after 5 second exposing on light situation obtained the higher germination percentage compared to the constant darkness situation. Also $76 \%$ of summer, $56 \%$ of winter and uncategorized annual weeds presented the higher germination percentage when under briefly light situation pattern compared to constant darkness condition. $17 \%$ of species under the constant light had low or no significant different germination compared to the light treatment [9]. Campsis radicans germination rate under the light absence situation was less than $15 \%$, the highest germination rate achieved at $12 \mathrm{hrs}$ of lightning periods [10]. The light is a common necessity for weeds germination [11]. The light exposing treatment stimulate weeds germination, however there are species that never react to light; in some cases it can procrastinate their germination. Rumex obtusifolius and Silenen octiflora would have a dull germination rate if they exposed under the light situation before [12]. Lightning/darkness and constant darkness situation on Ceratocarpus arenarius had the same effect on its germination [13].

The temperature alternation might affect on some of these pivotal metabolic process. Not only the winter or early spring's cool temperatures detriments the active seeds metabolism, but also it prevents the seed germination; however it eliminates the seed dormancy in some species. Conversely, the warm 
spring and summer's temperatures increase the seeds metabolism by anticipating or stimulating the necessary biochemical reaction for germinating the active seeds [14].

Alternative temperatures play a major role in some weeds germinating process [15]. The effect of temperature fluctuations associated with fluctuation ranges (the difference between maximum and minimum temperature), temperature average and temperature periods; the reason of this is still obscure [16]. Evidence showed the alternative temperature alters the large seed molecules construction that directly inhibits germination process and balance the aspiration products through the high temperature cycle [17]. At 10/25, 15/30 and 5/20 ${ }^{\circ} \mathrm{C}$ Salsola villosa had the highest germination percentage; also the highest germination rate devoted to $15 / 30$ and $10 / 25{ }^{\circ} \mathrm{C}$. The lowest percentage and germination rate pertained to $40 / 25{ }^{\circ} \mathrm{C}$ alternative temperature [18]. Hence, purslane is one of the tenth dangerous weeds in the world, this study aimed to recognize the effects of lightning and different temperature situations on purslane germination to get the appropriate way to control it.

\section{MATERIALS AND METHODS}

\section{Investigation of seed viability}

Purslane seeds population randomly aggregated in 2011 from abundant shrubs of around five square kilometer at Karaj and Ahvaz. Then seeds disinfected with carbendazim fungicide at 1:1000 for 5 minutes, afterward seeds rinsed with sterilized water and settled in the room temperature in order to be dried [19]. Purslane seeds viability was determined by tetrazolium chloride test. Hence, 50 unites of each two purslane populations arranged in four replications to treat with tetrazolium chloride solution $1 \%$ at $30{ }^{\circ} \mathrm{C}$ in darkness for $48 \mathrm{hrs}$ [20]. Alive seeds, which became red through thetetrazolium chloride test distinguished away.

Determining the main temperatures of germination

To assess the main temperatures on germination percentage of two purslane populations (Karaj and Ahvaz), experiment conducted on constant temperatures at $(5,10,15,20,25,30,35,40$ and 45 $\left.{ }^{\circ} \mathrm{C}\right)$ under the two light regimes (12/12 hrs light/darkness and permanent darkness). To investigate the permanent darkness effect on seeds germination, they (petri dishes) wrapped by twofold of aluminum papers.

Investigation of alternative temperatures on germination

In this research the behavior of two purslane populations (Karaj and Ahvaz) was studied under the alternative temperatures (day/night) at 15/5, 20/10, $25 / 15,30 / 20,35 / 25,40 / 30,20 / 5,25 / 10,30 / 15$ and $35 / 20^{\circ} \mathrm{C}$.

Investigation of light rotation on germination Hence, the thermal rotation of $30 / 20$ in two populations showed the highest germination percentage, the effect of different light/darkness periods $(0 / 24,24 / 0,12 / 12,14 / 10,10 / 14,16 / 8$ and $8 / 16$ ) on germination percentage of two aforementioned populations is assessed on $30 / 20{ }^{\circ} \mathrm{C}$. All experiments arranged in a randomized complete block design with four replications. To investigate the germination capability on different thermal and lightning situations, 25 unites of seeds settled in $8 \mathrm{~cm}$ petri dishes, which contained sieve papers and $6 \mathrm{ml}$ of sterilized water. Afterward, they transmitted to the germinator under predetermined thermal and lightning situations; then after fourteen days the seed germination percentage assessed. The seeds, which had $2 \mathrm{~mm}$ radicle length or rather, distinguished as germinated seeds. Ultimately after initial data analyzing and evaluation of their distribution, data analysis was done with utilizing the SAS software ver. 9.1. The comparison means assessed with Duncan's multiple-range test and graphs were draw with Excel software.

\section{RESULTS AND DISCUSSION}

\section{Investigation the viability and 1000 grain yield of purslane}

In this study the viability of Karaj and Ahvaz seeds respectively calculated about 95 and $97 \%$ (there was no statistical difference). According to ISTA process, thousand seeds randomly selected and scaled accurately by digital scale to assess the 1000 grain weight of seeds. The 1000 grain weight of Karaj and Ahvaz population respectively recorded about 0.47 and $0.49 \mathrm{~g}$ (difference statistically was insignificant).

\section{Purslane percentage and germination rate}

Generally the Karaj germination percentage was rather than Ahvaz population in the term of constant temperatures. Compression mean result of the constant temperature and light rotation effects on seeds germination showed at 5 and $45^{\circ} \mathrm{C}$ neither of the both populations germinated; also the maximum germination percentage of Karaj (permanent darkness) and Ahvaz (12/12 hrs light/darkness) population respectively observed at 25 and $30{ }^{\circ} \mathrm{C}$ (optimum temperature) (Figure 1). Furthermore, it is reported Rumex obtusifolius seeds under the light and darkness regimes germinated at the immense range of temperature $\left(10\right.$ to $\left.35{ }^{\circ} \mathrm{C}\right)$ [21]. The maximum germination occurred at 20 and $25{ }^{\circ} \mathrm{C}$, also at the bare minimum temperature $\left(5^{\circ} \mathrm{C}\right)$ and maximum temperature $\left(40{ }^{\circ} \mathrm{C}\right)$ no germination occurred. By investigating the constant temperatures $(15,20,25$, 30 and $35{ }^{\circ} \mathrm{C}$ ) on Amaranthus retroflexus, Datura stramonium and Echinochloa crus-guli germination it is cleared that at the ranges of 25 to $30{ }^{\circ} \mathrm{C}$ the germination percentage of $A$. retroflexus and $D$. stramonium was at the highest point; whereas in either of the five different temperatures, E. crus-guli germination percentage was at the lowest point. Moreover, the higher germination percentage is pertained to the high seed weight in weeds [22]. Reaction to the temperature is in conjunction with factors like species, environmental circumstances, seed quality and passed time after the maturity stage 
[23]. As figure 2 presented the alternation of germination rate in 9 different temperatures, the highest germination rate in Karaj (permanent darkness) and Ahvaz (12/12 hrs light/darkness) population achieved at 25 and $30{ }^{\circ} \mathrm{C}$ and also the lowest rate pertained to 5 and $45{ }^{\circ} \mathrm{C}$ (Figure 2). By investigating the thermal treatments $(5,10,15,20$, $25,30,35,40$ and $45{ }^{\circ} \mathrm{C}$ ) it is founded that the highest germination rate of Portulaca oleracea, Chenopodium album and Digitaria sanguinalis achieved at 25 to $35{ }^{\circ} \mathrm{C}$ temperature ranges, which support the current study [24]. Hence, the accurate recognition of purslane seed's optimum germinating temperature leads to determine the appropriate preemergence herbicide application time to control it.

The variations of alternative temperature (day/night) on purslane germinating percentage showed, by increasing temperature subsequently the germination rate increased; so that the maximum germination percentage under the $30 / 20{ }^{\circ} \mathrm{C}$ alternative temperature in Karaj and Ahvaz population respectively attained to 91 and $93.5 \%$. However by increasing temperature to $35 / 20,35 / 25$ and $40 / 30{ }^{\circ} \mathrm{C}$ the germination percentage of Karaj and Ahvaz population decreased respectively about 5/68, 42 and 75/75\% (Karaj) and 5/82, 75/61 and 14\% (Figure 3).

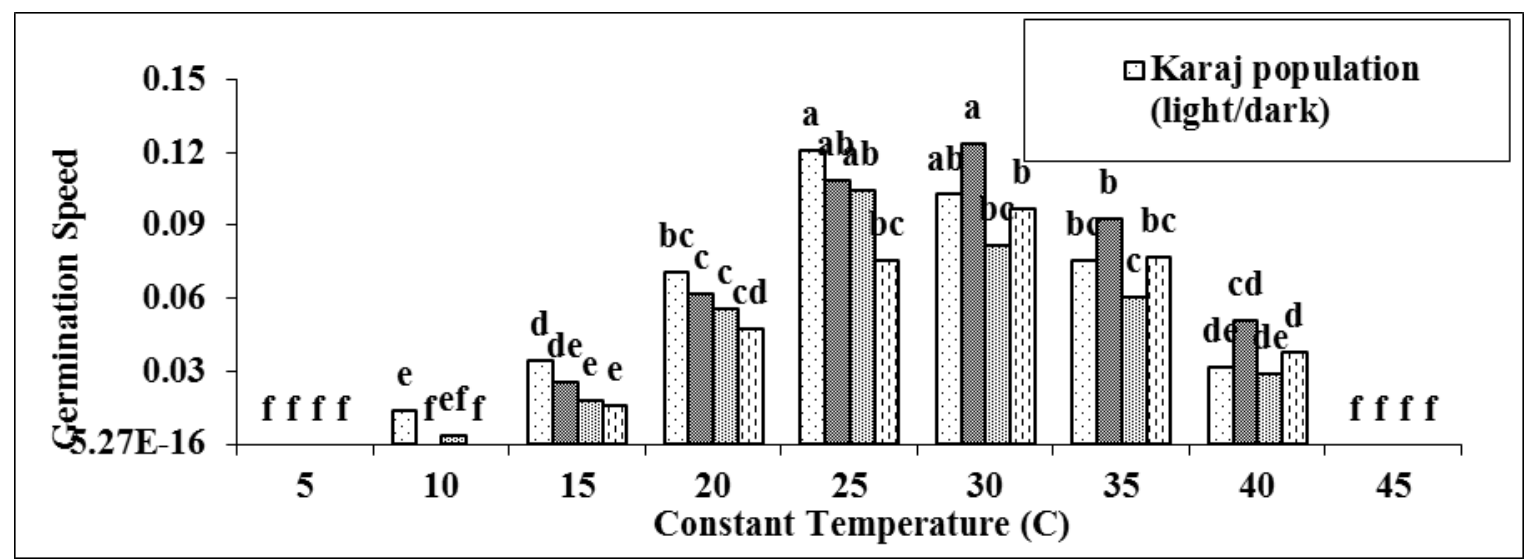

Figure 1-Effect of constant temperatures on germination percentage of two purslane populations (Karaj and Ahvaz) under two light regimes (12/12 hrs light/darkness and continuous darkness)

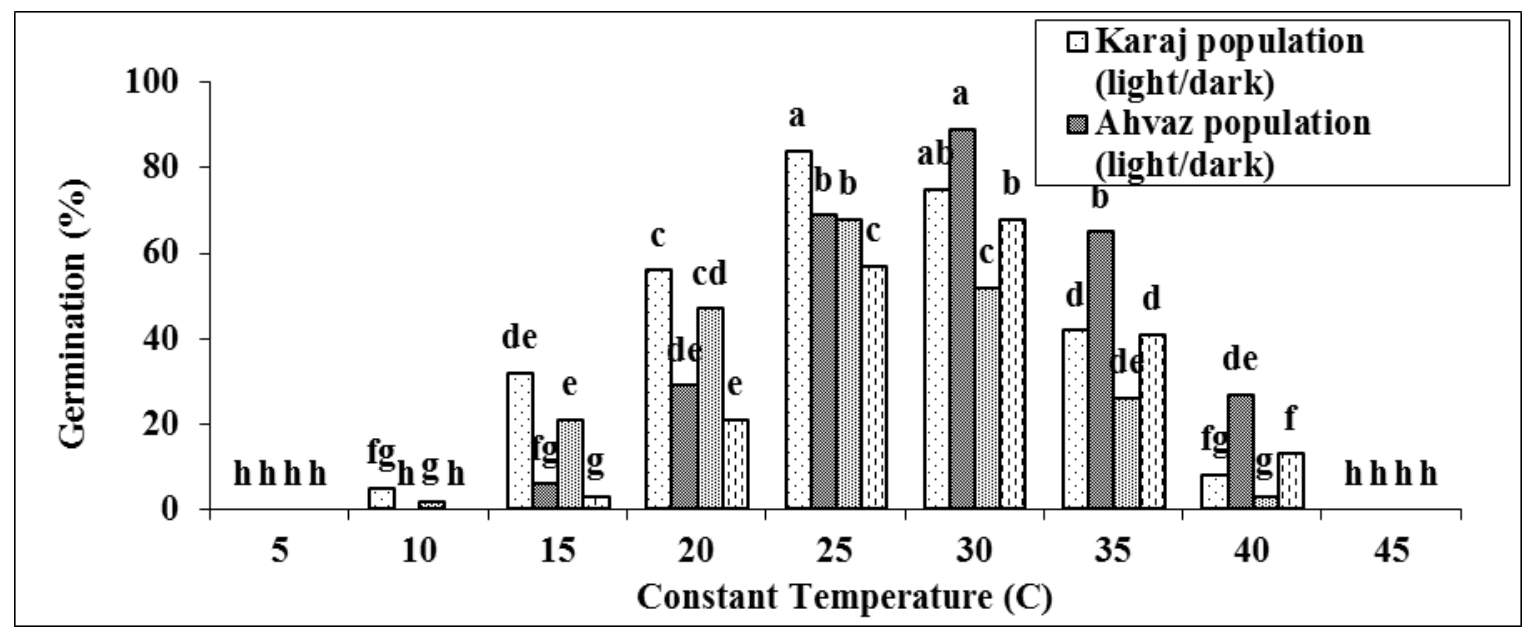

Figure 2-Effect of constant temperatures on germination rate of two purslane populations (Karaj and Ahvaz) under two light regimes (12/12 hrs light/darkness and continuous darkness)

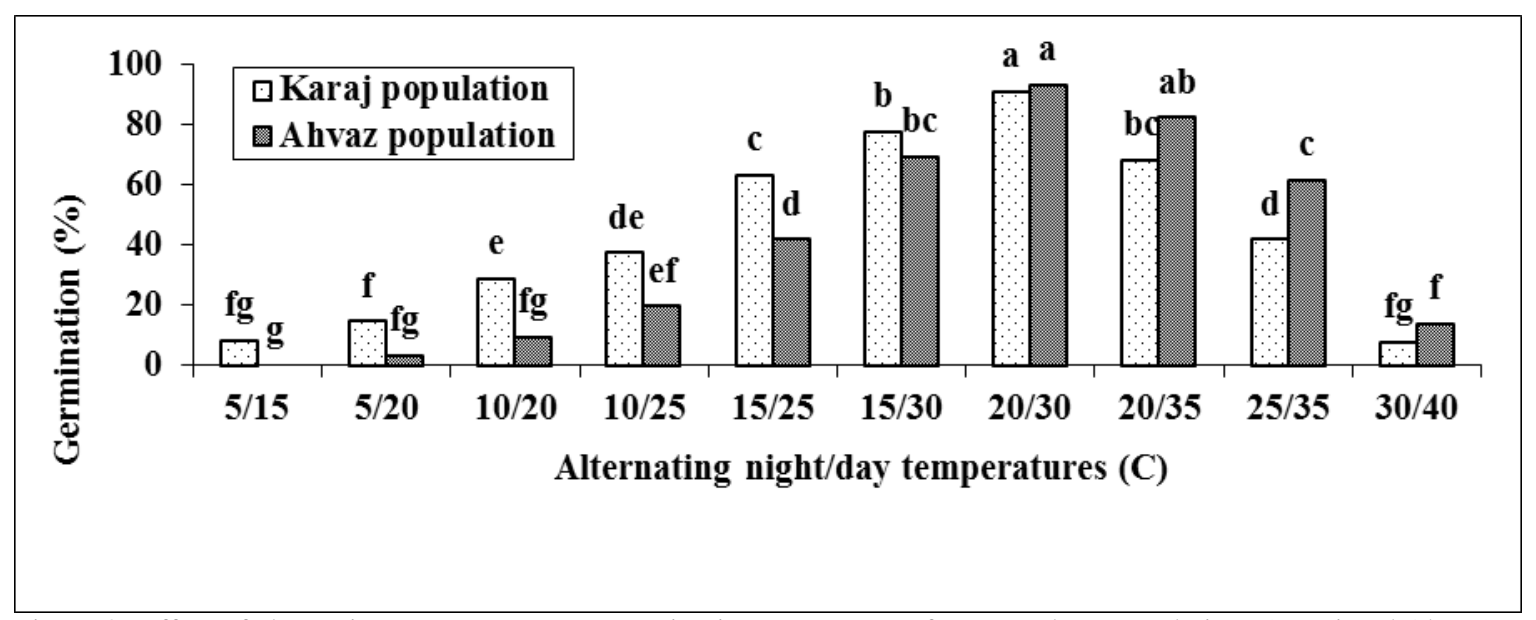

Figure 3- Effect of alternating temperatures on germination percentage of two purslane populations (Karaj and Ahvaz) 
So reaction to temperature might be differed among germinating process [25]. In the same research it is reported that the highest germination rate $(60 \%)$ of Hibiscus trionum seeds achieved at 20/30 ${ }^{\circ} \mathrm{C}$ alternative temperature; also at constant temperatures of 10 and $45^{\circ} \mathrm{C}$ neither of seeds germinated [26].

Researchers reported $25 / 20$ to $35 / 30{ }^{\circ} \mathrm{C}$ (day/night) is the appropriate temperature for Biden spilosa germination. They also added at lower temperatures from $15 / 10{ }^{\circ} \mathrm{C}$ and higher temperatures from $45 / 40$
${ }^{\circ} \mathrm{C}$ germination had descending rates [27]. In the most situations, when the seeds simultaneously exposed to the light and alternative temperature the percentage and the ultimate germination rate increase [28]. It is reported the optimum germination of Solanum sarrachoides occurred at 27 and $33^{\circ} \mathrm{C}$ [29]. Conversely, the optimum temperature for Beckmannia syzigachne germination is about $10{ }^{\circ} \mathrm{C}$ reported by [30]. Also the alternative temperatures effect on germination rate was similar to germination

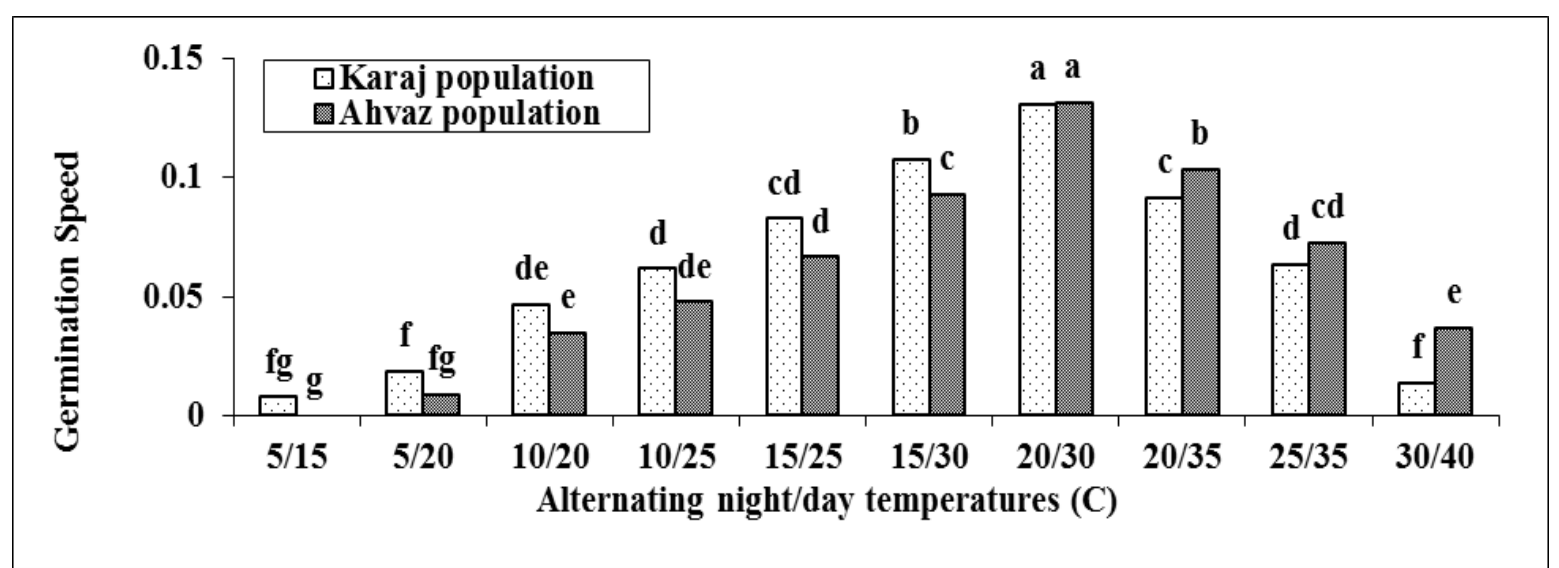

Figure 4- Effect of alternating temperatures on germination rate of two purslane populations (Karaj and Ahvaz)

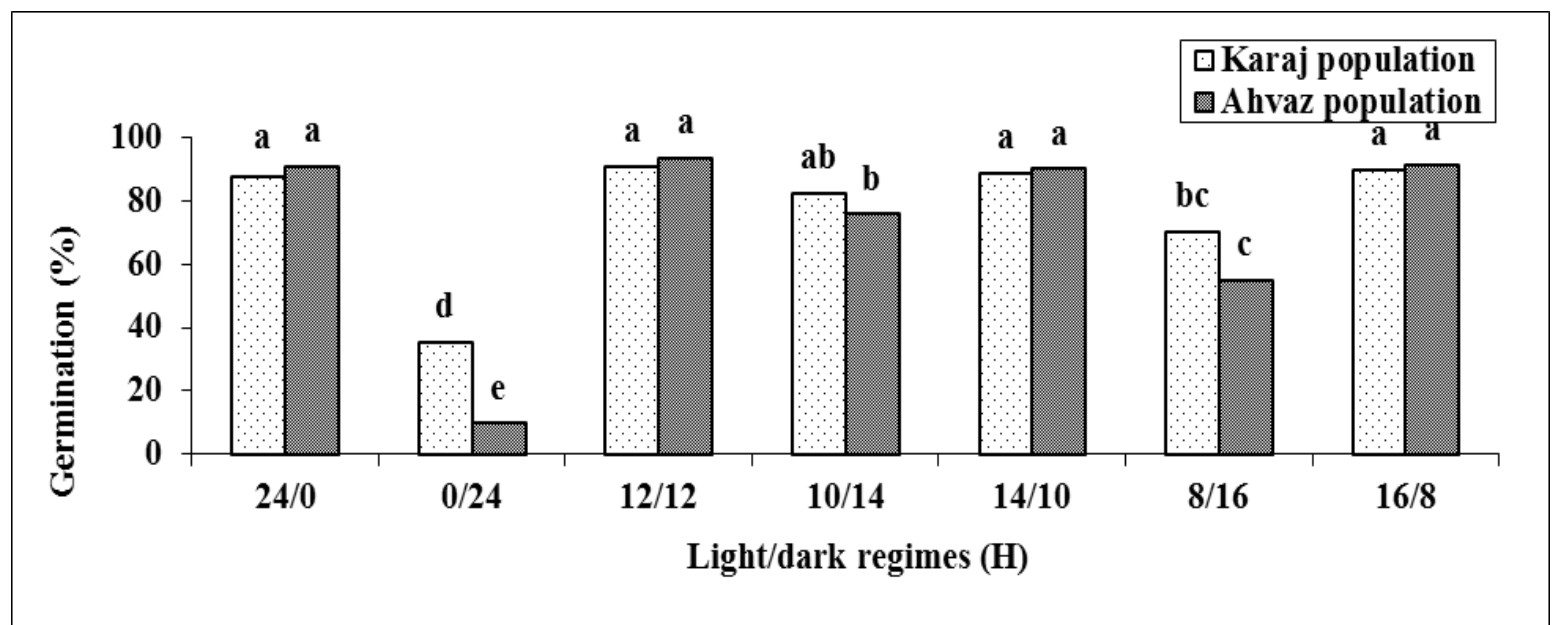

Figure 5- The effect of different periods of dark / light on germination percentage of two purslane populations (Karaj and Ahvaz)

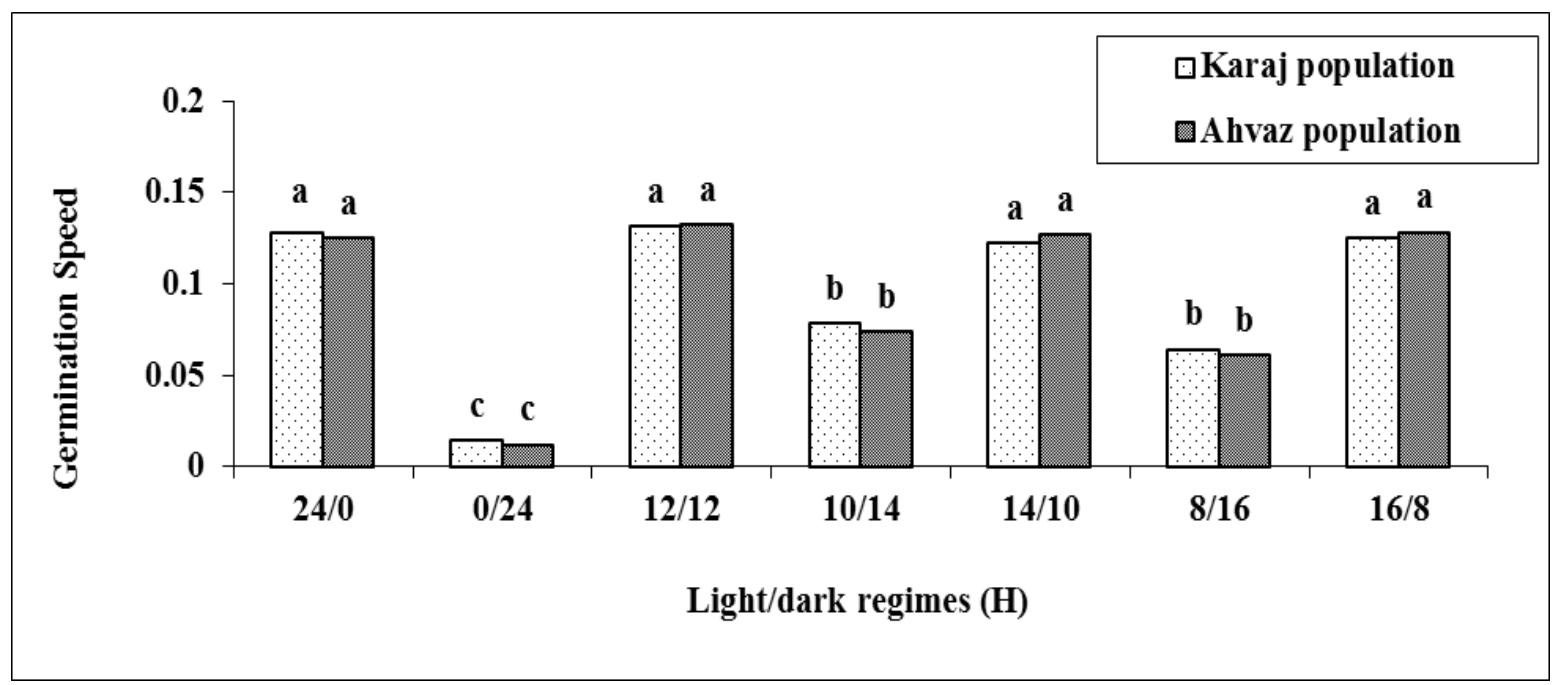

Figure 6- The effect of different periods of dark / light on germination rate of two purslane populations (Karaj and Ahvaz) 
percentage; so that, at $20 / 30{ }^{\circ} \mathrm{C}$ alternative temperature both of populations had the highest germination percentage but at $40 / 30$ and $15 / 5{ }^{\circ} \mathrm{C}$ the lowest value of this trait achieved for both (Figure 4). By investigating the alternative temperature effect (light/darkness) $16 / 8\left(20{ }^{\circ} \mathrm{C}\right.$ constant temperature $)$ and $16 / 8$ (16hrs at $25{ }^{\circ} \mathrm{C}$ and $8 \mathrm{hrs}$ at $30{ }^{\circ} \mathrm{C}$ ) on four Amaranthus species (A. deflexus, A. hybridus, A. spinosus and $A$. viridis), the highest rate of germination percentage in four species recorded at alternative temperature of $8 / 16\left(16 \mathrm{hrs}\right.$ at $25^{\circ} \mathrm{C}$ and 8 hrs at $30{ }^{\circ} \mathrm{C}$ ); this increasing ratio was more conspicuous for A. deflexus and A. spinosus species [31]. It is reported, the high germination rate of Conyza Canadensis occurred at alternative temperature of $24 / 20{ }^{\circ} \mathrm{C}$ (day/night) under the light situation. Although $C$. Canadensis could germinate under the two situations of light/darkness (13 hrs light period) and permanent darkness, it germinated just about $15 \%$ under the darkness situation compared to lightning situation of about 0 to $61 \%$ [6]. Usually alternative temperatures increased the germination rate of E. crus-guli, C. album and A. retroflexsus [32].

Also the effect of different dark/light periods on purslane germinating percentage showed the lowest germinating percentage in permanent darkness $(24 / 0)$ in Karaj and Ahvaz population respectively was 35.5 and $9.75 \%$; the highest germinating percentage in two populations respectively observed at $0 / 24,12 / 12$, $10 / 14$ and 8/16 treatments, which had no statistical different with each other (Figure 5). It seems that light rotation is essential for purslane germination. On the other hand light rotation plays a major role to motivate the seed germination. The positive response of purslane seeds to light reveals its photoblastic trait. So being under the plant remnants or lying in the soil (plough) prevents purslane germination. The

Table 1-Effect of constant temperatures of two populations (Karaj and Ahvaz) under two light regimes

(12/12 hrs light/dark and continuous dark) on seedling emergence of purslane

\begin{tabular}{|c|c|c|c|c|}
\hline Treatment & $\begin{array}{c}\text { Karaj } \\
\text { population } \\
\text { (light/dark) }\end{array}$ & $\begin{array}{c}\text { Karaj } \\
\text { population } \\
\text { (dark) }\end{array}$ & $\begin{array}{c}\text { Ahvaz } \\
\text { population } \\
\text { (light/dark) }\end{array}$ & $\begin{array}{c}\text { Ahvaz population } \\
\text { (dark) }\end{array}$ \\
\hline $\begin{array}{c}\text { Constant } \\
\text { Temperature }(\mathrm{C})\end{array}$ & \multicolumn{4}{|c|}{ Radicle length (mm) } \\
\hline 5 & $0.0 \mathrm{~h}$ & $0.0 \mathrm{~h}$ & $0.0 \mathrm{~h}$ & $0.0 \mathrm{~h}$ \\
\hline 10 & $3.12 \mathrm{fg}$ & $1.37 \mathrm{~g}$ & $0.0 \mathrm{~h}$ & $0.0 \mathrm{~h}$ \\
\hline 15 & $8.63 \mathrm{de}$ & $6.44 \mathrm{e}$ & $4.16 \mathrm{f}$ & $2.85 \mathrm{fg}$ \\
\hline 20 & $13.96 \mathrm{bc}$ & $10.72 \mathrm{~d}$ & $8.42 \mathrm{de}$ & $5.26 \mathrm{ef}$ \\
\hline 25 & $17.42 \mathrm{a}$ & $15.53 \mathrm{ab}$ & $14.73 b$ & $10.22 \mathrm{~d}$ \\
\hline 30 & $16.31 \mathrm{ab}$ & $13.96 \mathrm{bc}$ & $17.68 \mathrm{a}$ & $14.65 \mathrm{~b}$ \\
\hline 35 & $12.74 \mathrm{c}$ & $8.34 \mathrm{de}$ & $13.87 \mathrm{bc}$ & $10.23 \mathrm{~d}$ \\
\hline 40 & $4.52 \mathrm{f}$ & $3.11 \mathrm{fg}$ & $7.35 \mathrm{e}$ & $4.67 \mathrm{f}$ \\
\hline 45 & $0.0 \mathrm{~h}$ & $0.0 \mathrm{~h}$ & $0.0 \mathrm{~h}$ & $0.0 \mathrm{~h}$ \\
\hline $\begin{array}{c}\text { Constant } \\
\text { Temperature }(\mathrm{C})\end{array}$ & \multicolumn{4}{|c|}{ Shoot length (mm) } \\
\hline 5 & $0.0 \mathrm{~h}$ & $0.0 \mathrm{~h}$ & $0.0 \mathrm{~h}$ & $0.0 \mathrm{~h}$ \\
\hline 10 & $2.87 \mathrm{f}$ & $1.12 \mathrm{~g}$ & $0.0 \mathrm{~h}$ & $0.0 \mathrm{~h}$ \\
\hline 15 & $5.26 \mathrm{e}$ & $3.28 \mathrm{f}$ & $3.43 \mathrm{f}$ & $2.11 \mathrm{fg}$ \\
\hline 20 & $11.46 \mathrm{bc}$ & $7.31 \mathrm{de}$ & $9.61 \mathrm{~cd}$ & $5.32 \mathrm{e}$ \\
\hline 25 & $15.23 \mathrm{a}$ & $12.54 \mathrm{bc}$ & $13.24 \mathrm{~b}$ & $10.46 \mathrm{c}$ \\
\hline 30 & $13.71 \mathrm{~b}$ & $9.63 \mathrm{~cd}$ & $15.8 \mathrm{a}$ & $13.89 \mathrm{~b}$ \\
\hline 35 & $8.95 \mathrm{~d}$ & $6.77 \mathrm{de}$ & $11.96 b c$ & $8.56 \mathrm{~d}$ \\
\hline 40 & $3.22 \mathrm{f}$ & $2.65 \mathrm{f}$ & $6.32 \mathrm{e}$ & $3.07 \mathrm{f}$ \\
\hline 45 & $0.0 \mathrm{~h}$ & $0.0 \mathrm{~h}$ & $0.0 \mathrm{~h}$ & $0.0 \mathrm{~h}$ \\
\hline $\begin{array}{c}\text { Constant } \\
\text { Temperature }(\mathrm{C})\end{array}$ & \multicolumn{4}{|c|}{ Seedling fresh weight $(\mathrm{g})$} \\
\hline 5 & $0.0 \mathrm{~h}$ & $0.0 \mathrm{~h}$ & $0.0 \mathrm{~h}$ & $0.0 \mathrm{~h}$ \\
\hline 10 & $0.011 \mathrm{~g}$ & $0.007 \mathrm{~g}$ & $0.0 \mathrm{~h}$ & $0.0 \mathrm{~h}$ \\
\hline 15 & $0.046 \mathrm{e}$ & $0.031 \mathrm{f}$ & $0.023 \mathrm{f}$ & $0.018 \mathrm{fg}$ \\
\hline 20 & $0.095 \mathrm{c}$ & $0.075 \mathrm{~cd}$ & $0.075 \mathrm{~cd}$ & $0.46 \mathrm{e}^{\circ}$ \\
\hline 25 & $0.14 \mathrm{a}$ & $0.12 \mathrm{~b}$ & $0.12 \mathrm{~b}$ & $0.1 \mathrm{bc}$ \\
\hline 30 & $0.12 b$ & $0.089 \mathrm{c}$ & $0.15 \mathrm{a}$ & $0.13 \mathrm{ab}$ \\
\hline 35 & $0.063 \mathrm{~d}$ & $0.048 \mathrm{c}$ & $0.094 \mathrm{c}$ & $0.073 \mathrm{~cd}$ \\
\hline 40 & $0.024 \mathrm{f}$ & $0.018 \mathrm{fg}$ & $0.047 \mathrm{e}$ & $0.029 \mathrm{f}$ \\
\hline 45 & $0.0 \mathrm{~h}$ & $0.0 \mathrm{~h}$ & $0.0 \mathrm{~h}$ & $0.0 \mathrm{~h}$ \\
\hline
\end{tabular}

Means within a column followed by the same letters are not significantly difference at the $\alpha=0.05$ (Duncan's multiple-range test). 
large numbers of weeds germinate at permanent temperature, but their germination rate increase in alternative temperatures [29]. For example, $A$. retroflexsus and Cortaderia selloana germination is thrived from $30 \%$ to $90 \%$ in the alternative germinated rather than $80 \%$ under the light periods of 8,12 and $16 \mathrm{hrs}$ and $24 \mathrm{hrs}$ darkness [36]. The maximum germination rate $(92 \%)$ recorded at $12 \mathrm{hrs}$ of light period. At constant temperature of $15{ }^{\circ} \mathrm{C}$ the Poa pratensis germination rate under the light

Table 2- Effect of alternating temperatures on purslane seedling emergence

\begin{tabular}{|c|c|c|c|c|c|c|}
\hline \multirow{2}{*}{$\begin{array}{l}\text { Alternating } \\
\text { night/day } \\
\text { temperatures } \\
\text { (C) }\end{array}$} & \multicolumn{2}{|c|}{$\begin{array}{l}\text { Radicle length } \\
\text { (mm) }\end{array}$} & \multicolumn{2}{|c|}{$\begin{array}{l}\text { Shoot length } \\
\qquad(\mathrm{mm})\end{array}$} & \multicolumn{2}{|c|}{$\begin{array}{l}\text { Seedling fresh weight } \\
(\mathrm{g})\end{array}$} \\
\hline & $\begin{array}{l}\text { Karaj } \\
\text { popul } \\
\text { ation }\end{array}$ & $\begin{array}{c}\text { Ahvaz } \\
\text { population }\end{array}$ & $\begin{array}{c}\text { Karaj } \\
\text { populat } \\
\text { ion }\end{array}$ & $\begin{array}{c}\text { Ahvaz } \\
\text { population }\end{array}$ & $\begin{array}{c}\text { Karaj } \\
\text { populati } \\
\text { on }\end{array}$ & $\begin{array}{c}\text { Ahvaz } \\
\text { population }\end{array}$ \\
\hline $5 / 15$ & $2.08 \mathrm{~h}$ & $0 \mathrm{i}$ & $1.01 \mathrm{gh}$ & $0 \mathrm{~h}$ & $0.011 \mathrm{ef}$ & $0 \mathrm{f}$ \\
\hline $5 / 20$ & $3.71 \mathrm{~g}$ & $0.86 \mathrm{hi}$ & $2.93 \mathrm{~g}$ & $0.08 \mathrm{gh}$ & $0.028 \mathrm{e}$ & 0.012 ef \\
\hline $10 / 20$ & $\begin{array}{c}6.34 \\
\mathrm{fg}\end{array}$ & $4.14 \mathrm{~g}$ & $5.16 \mathrm{f}$ & $2.27 \mathrm{~g}$ & $0.056 \mathrm{~d}$ & $0.031 \mathrm{e}$ \\
\hline $10 / 25$ & $7.12 \mathrm{f}$ & $5.83 \mathrm{fg}$ & 7.47 e & $5.13 \mathrm{f}$ & $0.074 \mathrm{~cd}$ & $0.063 \mathrm{~d}$ \\
\hline $15 / 25$ & $\begin{array}{l}12.45 \\
\mathrm{~cd}\end{array}$ & $10.95 \mathrm{~d}$ & $10.75 \mathrm{~d}$ & $9.82 \mathrm{de}$ & $0.096 \mathrm{c}$ & $0.082 \mathrm{~cd}$ \\
\hline $15 / 30$ & $\begin{array}{c}15.68 \\
b\end{array}$ & $13.86 \mathrm{c}$ & 13.b & $12.54 \mathrm{c}$ & $0.132 \mathrm{~b}$ & $0.121 \mathrm{bc}$ \\
\hline $20 / 30$ & $\begin{array}{c}17.42 \\
\mathrm{a}\end{array}$ & $18.1 \mathrm{a}$ & $15.72 \mathrm{a}$ & $16.1 \mathrm{a}$ & $0.158 \mathrm{a}$ & $0.161 \mathrm{a}$ \\
\hline $20 / 35$ & $\begin{array}{c}13.69 \\
\mathrm{c}\end{array}$ & $16.08 \mathrm{~d}$ & $12.69 \mathrm{c}$ & $14.73 \mathrm{ab}$ & $0.105 \mathrm{c}$ & $0.129 \mathrm{~b}$ \\
\hline $25 / 35$ & $9.25 \mathrm{e}$ & $11.55 \mathrm{~d}$ & $9.25 \mathrm{de}$ & $10.45 \mathrm{~d}$ & $0.075 \mathrm{~cd}$ & $0.084 \mathrm{~cd}$ \\
\hline $30 / 40$ & $1.73 \mathrm{~h}$ & $3.13 \mathrm{gh}$ & $1.67 \mathrm{~g}$ & $3.21 \mathrm{f}$ & $0.026 \mathrm{e}$ & $0.041 \mathrm{de}$ \\
\hline
\end{tabular}

temperature [33]. Rumex obtusifolius and Silene noctiflora seeds when placed utterly in the darkness had the duller germination rate [12]. Amaranthus retroflexus, Chenopodium album and Ambrosia artemisiifolia seeds in the light situation had the higher germination percentage compared to darkness [34]. It should be considered that the light response differs between weed species. The seed of some species germinate equally under the light and darkness situations [35]. For example, Macdonald et al. perceived Eupatorium capillifolium seeds are intensively photoblastic and neither of them germinated in darkness; whereas Eupatorium compositifolium seeds were moderately photoblastic and germinated about $12 \%$ in the darkness. Also the two broadleaf and tropical species of Corchorus olitorius and Melochia concatenate do not response to light treatments reported by [4]. According to result, the different light/dark periods effect on germination rate showed, the lowest germination rate between Karaj and Ahvaz population under the permanent darkness $(0 / 24)$, which statistically was no significant difference between two populations (Figure 6). Hyparrhenia hirta as a $\mathrm{C}_{4}$ grass was briefly eager to germinate under the light situation, however the light period length was not effective on germination rate in this term; so that their seed situation was rather compared to darkness reported by [37].

\section{Purslane radicle length}

The compression mean result of constant temperatures effect on radicle length under the two light regimes showed at 5 and $45{ }^{\circ} \mathrm{C}$, there was no record about radicle length increase in two populations under the two light regimes (12/12 hrs light/darkness and permanent darkness); whereas by increasing temperature from 10 to $30{ }^{\circ} \mathrm{C}$, radicle length linearly increased in two populations under the aforementioned light regimes. Increasing temperature from the optimum level of length development (25 to 30), make a significant alternation in radicle length development rate; so that $30{ }^{\circ} \mathrm{C}$ can be set as maximum radicle length temperature for weeds. The temperature ranges of 10 to $30{ }^{\circ} \mathrm{C}$ are biologic inhibitors for radicle length development and the ranges of 25 to $30{ }^{\circ} \mathrm{C}$ are distinguished as optimum temperatures for radicle length development (Table 1). According to study about constant temperatures effect on Hordiunm spontaneum Koch radicle length it is founded that by increasing temperature from 5 to $25{ }^{\circ} \mathrm{C}$, the radicle length consecutively showed ascendant development; this ascending ratio collapsed when the temperature 
increased from 25 to $40{ }^{\circ} \mathrm{C}$ [38]. The result of alternative temperatures effect on radicle length showed at $30 / 20{ }^{\circ} \mathrm{C}$ (light/darkness) treatment, Karaj and Ahvaz population respectively had the highest radicle length (about 17.42 and $18.1 \mathrm{~mm}$ ). The lowest radicle length in two populations was 2.08 and $0 \mathrm{~mm}$ at $15 / 5{ }^{\circ} \mathrm{C}$ (Table 2). According to these results by getting away from the optimum temperature $(30 / 20)$ the variations between radicle lengths tends to decrease. Radicle length at $15 / 5$, $20 / 5,20 / 10,25 / 10,25 / 15$ and 30/15 compared to $35 / 20,35 / 25$ and $40 / 30$ showed the rather reduction. Different darkness/light period's effect on radicle length showed the lowest radicle length in two populations pertained to permanent darkness (24/0); which respectively had 91 and $95 \%$ reduction in aforementioned trait compared to constant lightning (0/24). Among different darkness/light periods (24/0, $12 / 12,10 / 14$ and $8 / 16$ ) there were no statistical difference in the term of radicle length (Table 3 ). The Purslane root production potential in the immense light ranges made it able to develop in various seasons if the environmental situation be appropriate.
16.1 $\mathrm{mm}$ at $30 / 20{ }^{\circ} \mathrm{C}$ (Table 2). According to the result the shoot development reduction in lower temperatures was more conspicuous than the higher ones. This reduction rate addressed the lower temperatures as a natural thermo-ecologic solution to control shoot length in this plant. In this research the highest shoot length in different light periods (dark/light) at $12 / 12,10 / 14,8 / 16$ and $0 / 24$ respectively achieved to $15.72,15.23,14.75$ and $13.65 \mathrm{~mm}$ in Karaj population and 16.1, 15.78, 14.25 and $14.11 \mathrm{~mm}$ in Ahvaz population, which statistically had no significant difference with each other. Also the lowest recorded shoot length was respectively pertained to Karaj $(2.46 \mathrm{~mm})$ and Ahvaz $(1.75 \mathrm{~mm})$ population under the permanent darkness $(0 / 24)$ (Table 3). The more blatant shoot length reduction under the permanent darkness compared to dark/light situation in $S$. rebaudiana, S. scalrea, Tagetes minutia and Xanthium strumarium $\mathrm{L}$ is reported by [8, 39].

Purslane fresh seedling weight

The result showed the highest fresh seedling weight in both populations under the two light regimes and

Table 3 - The effect of different periods of dark / light on purslane seedling emergence

\begin{tabular}{|c|c|c|c|c|c|c|}
\hline \multirow{2}{*}{$\begin{array}{l}\text { Light/dark } \\
\text { regimes } \\
(\mathrm{H})\end{array}$} & \multicolumn{2}{|c|}{$\begin{array}{l}\text { Radicle length } \\
\text { (mm) }\end{array}$} & \multicolumn{2}{|c|}{$\begin{array}{l}\text { Shoot length } \\
(\mathrm{mm})\end{array}$} & \multicolumn{2}{|c|}{ Seedling fresh weight $(\mathrm{g})$} \\
\hline & $\begin{array}{c}\text { Karaj } \\
\text { population }\end{array}$ & $\begin{array}{c}\text { Ahvaz } \\
\text { population }\end{array}$ & $\begin{array}{c}\text { Karaj } \\
\text { population }\end{array}$ & $\begin{array}{c}\text { Ahvaz } \\
\text { population }\end{array}$ & $\begin{array}{c}\text { Karaj } \\
\text { population }\end{array}$ & $\begin{array}{c}\text { Ahvaz } \\
\text { population }\end{array}$ \\
\hline $24 / 0$ & $17.4 \mathrm{a}$ & $17.1 \mathrm{a}$ & $13.65 \mathrm{a}$ & $14.11 \mathrm{a}$ & $0.141 \mathrm{a}$ & $0.152 \mathrm{a}$ \\
\hline $0 / 24$ & $1.58 \mathrm{c}$ & $0.94 \mathrm{c}$ & $2.46 \mathrm{~d}$ & $1.75 \mathrm{~d}$ & $0.048 \mathrm{bc}$ & $0.022 \mathrm{~b}$ \\
\hline $12 / 12$ & $17.42 \mathrm{a}$ & $17.32 \mathrm{a}$ & $15.72 \mathrm{a}$ & $16.1 \mathrm{a}$ & $0.158 \mathrm{a}$ & $0.161 \mathrm{a}$ \\
\hline $10 / 14$ & $9.42 \mathrm{~b}$ & $8.34 \mathrm{~b}$ & $11.17 \mathrm{~b}$ & $10.34 \mathrm{~b}$ & $0.095 \mathrm{~b}$ & $0.075 \mathrm{bc}$ \\
\hline $14 / 10$ & $16.84 \mathrm{a}$ & $17.56 \mathrm{a}$ & $15.23 \mathrm{a}$ & $15.78 \mathrm{a}$ & $0.138 \mathrm{a}$ & $0.141 \mathrm{a}$ \\
\hline $8 / 16$ & $8.75 \mathrm{~b}$ & $6.32 \mathrm{~b}$ & $7.35 \mathrm{c}$ & $5.98 \mathrm{c}$ & $0.062 \mathrm{bc}$ & $0.052 \mathrm{bc}$ \\
\hline $16 / 8$ & $16.83 \mathrm{a}$ & $17.21 \mathrm{a}$ & $14.75 \mathrm{a}$ & $14.25 \mathrm{a}$ & $0.143 \mathrm{a}$ & $0.138 \mathrm{a}$ \\
\hline
\end{tabular}

\section{Purslane shoot length}

The result showed the shoot length developing rate altered considerably under the different temperatures and light regimes. So that by increasing temperature from 5 to $30{ }^{\circ} \mathrm{C}$, the shoot length subsequently increased; but by adding the temperature degree from $30{ }^{\circ} \mathrm{C}$ to higher levels under the light situation decreased the shoot length of two populations. Furthermore at $45^{\circ} \mathrm{C}$ the shoot length utterly ceased (Table 1). It is reported there is ascending correlation between increasing the shoot length and increasing temperature from 10 to $30{ }^{\circ} \mathrm{C}$, but the more increasing temperature from 30 to $35{ }^{\circ} \mathrm{C}$ had a converse effect on shoot length [39]. According to result (Table 1) Karaj population (dark) showed the rather shoot development at temperatures of about 5 to $25{ }^{\circ} \mathrm{C}$ under the darkness/light situation compared to Ahvaz population (dark and dark/light); but in rather temperatures (over $25^{\circ} \mathrm{C}$ ) Ahvaz population (dark/light) obtained the greater value. In the term of alternative temperatures the lowest shoot length in Karaj and Ahvaz population respectively was 1.01 and $0 \mathrm{~mm}$ at $15 / 5$ (light/dark) ${ }^{\circ} \mathrm{C}$. Also the highest shoot length in both populations was about 15.72 and constant temperatures achieved at 25 to $30{ }^{\circ} \mathrm{C}$ (optimum temperature); so that the highest recorded of fresh seedling weight respectively pertained to Ahvaz (dark/light) and Karaj (dark/light) population just about 0.15 and $0.12 \mathrm{~g}$, which statistically had no significant difference with each other. Karaj populations under the two light regimes (dark/light and permanent darkness) in the lower temperatures from the optimum level consecutively made the higher fresh weight compared to Ahvaz population; in the higher temperatures from the optimum level showed the converse process (Table 1). At 5 and 45 ${ }^{\circ} \mathrm{C}$ no fresh seedling weight recorded in two populations.

Since the purslane seeds postpone its germination through the lower temperatures of the early developing season, by anticipating the target crops plantation, their competitive capability will increased opposed to weed species. It should be considered the late purslane germination make it able to elude the management operations. Hence most of the weed management strategies especially herbicide utilization accomplished at the early time of the developing season. The variations of purslane fresh 
seedling weight followed a quadratic course of action; so that the fresh seedling weight begins from $15 / 5{ }^{\circ} \mathrm{C}$ (day/night) as a fundamental temperature and picked to its highest level at $30 / 20{ }^{\circ} \mathrm{C}$ (optimum temperature) and then had a descending process (Table 2). The compression means result of light rotations effect on fresh seedling weight showed by increasing the darkness period amount of produced biomass from both populations reduced; the lowest biomass value respectively pertained to light rotation periods (dark/light) of 24/0,14/10 and 16/8, also other treatments had no significant difference with each other (Table 3 ).

\section{REFERENCES}

1. Koocheki A, Jami-al ahmadi M, Kamkar B and Mahdavidamghani AM. 2000. Ecological Prinnciples of Agriculture. Jahade-eDaneshghahi Mashhad Press (In Persian).

2. Forcella F, Benech-Arnold R, Sanchez and Ghersa CM. 2000. Modelling seedling emergence. Field Crops Research. 67: 123139.http://dx.doi.org/10.1016/s03784290(00)00088-5

3. Khan MA and Gulzar S. 2002. Germination responses Of Sporobolus ioclados: A salin desert grass. Journal Arid Environment. 53: $387-$ 394.http://dx.doi.org/10.1006/jare.2002.1045

4. Chauhan BS and Johnson DE. 2008. Germination ecology of Chinese sprangletop (Leptochloa chinensis) in the Philippines. Weed Science. 56: 820-825. http://dx.doi.org/10.1614/ws-08-070.1

5. Bewley JD and Black M. 1994. Seeds: Physiology of Development and Germination. $2^{\text {nd }}$ ed. New York: Plennum. Pp. 273-290.

6. Nandula VK, Eubank TWDH, Poston $\mathrm{CH}$, Koger and Reddy KN. 2006. Factors affecting germination of horseweed (Conyza canadensis). Weed Science, 54: 898-902.

http://dx.doi.org/10.1614/ws-06-006r2.1

7. Thomoson AJ., Jones NE and Blair AM. 2008. The effect of temperature on viability of imbibed weed seeds. Ann. Appl. Biol. 130 (1): 123 - 134. http://dx.doi.org/10.1111/j.1744-

7348.1997.tb05788.x

8. Kumar R and Sharma S. 2012. Effect of light and temperature on seed germination of important medicinal and aromatic plants in north western Himalayas. Bioresource Technology. 2(3): 468-475.

9. Andersson L, Milberg P and Noronha A. 1997. Germination response of weed seeds to light, light of short duration and darkness after stratification in soil. Swedish Journal of Agriculture 27: 113-120.

10. Chachalis D and Ready KN. 2000. Factors affecting Campsis radicans seed germination and seedling emergence. Weed Science: 48: 212216. http://dx.doi.org/10.1614/0043-

1745(2000)048[0212:facrsg]2.0.co;2

11. Egley GH, and Duke SO. 1985. Physiology of weed seed dormancy and germination. In Duke, S. O. (eds.), Weed Physiology. Reproduction and Eco-physiology. Boca Raton, FL. CRC. Volume I. Pp. 27-64.

12. Milberg P. 1997. Weed seed germination after short term light exposure: germination rate, photon flounce response and interaction with nitrate. Weed Research. 37: 157-164.

http://dx.doi.org/10.1046/j.1365-3180.1997.d0116.x

13. Ebrahimi E, Eslami SV, Jami Al-Ahmadi M and Mhamoodi S. 2012. Studying the Effect of Different Environmental Factors on Germination of (Ceratocarpus arenarius L. Bluk) Seed. Iranian Society of Weed Science. 7(1): 45-57.

14. Leon RG, Knapp AD and Own MDK. 2004. Effect of temperature on the germination of common waterhemp (Amaranthus tuberculatus), giant foxtail (Setaria faberi), and velvetleaf (Abutilon theophrasti). Weed Science. 52: 67-73. http://dx.doi.org/10.1614/p2002-172

15. Booth BD, Murphy SD and Swanton CJ. 2003. Weed ecology in natural and agricultural systems. Pp 93-94. CAB International. Wallingford.

16. Roberts HA and Lockett PM. 1978. Seed dormancy and field emergence in Solanum nigrum L. Weed Research. 18: 231-241. http://dx.doi.org/10.1111/j.1365-

3180.1978.tb01613.x

17. Chohen D. 1985. The mechanism of germination stimulation by alternating temperature. Bulletin of the Research Council of section D Botany D6: 111-117.

18. Mohammad Assaeed A. 2002. Effect of temperature and water potential on germination of Salsola villosa. Assiut Journal of Agricultural Science. 2: 173-183.

19. Pahlevani AH, Maighany F, Rashed MH, Baghestani MA, Nassiri $M$ and Ale-ebrahimi MT. 2008. Seed germination behavior of swallow wort (Cynanchum acutum). Iran. J. Field Crops Res. 5(1): 47-52.

20. Esno H, Solna H and Sweden M. 1996. Proceeding of the International Seed Testing Association. Wageningen, Thr Netherlands. p. 92.

21. Benvenuti S, Macchia M, and Miele S. 2001. Quantitative analysis of emergence of seedlings from buried weed seeds with increasing soil depth. Weed Science. 49:528-535. http://dx.doi.org/10.1614/00431745(2001)049[0528:qaoeos]2.0.co;2

22. Mehmeti A, Demaj A and Waldhardt R. 2010. Germination traits of three weed species in Kosovo. Web Ecol. 10: 15-22. http://dx.doi.org/10.5194/we-10-15-2010

23. Akram ghaderi F, Kamkar B and Soltani A. 2008. Principles of Seed Science and 
Technology. Mashhad Jahad-e Daneshgahi Press.

24. Poortousi N, Rashed Mohasel MH and Ezadi Darbandi E. 2008. Germination characteristics and cardinal temperatures of lambsquarter, purselane and crabgrass. Iranian Journal of Agricultural Researches. 6(2):255-261.

25. Hejazi A. 1994. Seed Technology Tehran University press Iran.

26. Chachalis D, Korres N, and Khah EM. 2008. Factors affecting seed germination and emergence of Venice mallow (Hibiscus trionum). Weed Science. 56: 509-515. http://dx.doi.org/10.1614/ws-07-144.1

27. Reddy KN and Singh M. 1992. Germination and emergence of hairy beggarticks (Biden spilosa). Weed Science. 40:195-199.

28. McDonald MB. 1985. Physical seed quality of soybean. Seed Science and Technology. 13: 601628.

29. Zhou J., Deckard EL and Ahrens WH. 2005. Factors affecting germination of hairy nightshade (Solanum sarrachoides) seeds. Weed Sci. 53: 41-45.

http://dx.doi.org/10.1614/ws-04-100r1

30. Rao N, Dong L, Li J and Zhang H. 2008. Influence of environmental factors on seed germination and seedling emergence of American slough grass (Becmania syzigachne). Weed Science. 56: 529-533. http://dx.doi.org/10.1614/ws-07-158.1

31. Carvaliho S and Christoffoleti PJ. 2007. Influence of light and temperature on germination of five weed species of the Amaranthus genus. Bragantia [online]. 66(4): 527-533. http://dx.doi.org/10.1590/S000687052007000400001

32. Martinez-Ghersa MA, Satorre EH and Chersa CM. 1997. Effect of soil water content and temperature on dormancy breaking and germination of three weeds. Weed Sci. 45: 791797.

33. Vitta JI and Faccini D. 2005. Germination characteristics of Amaranthus quitensis as affected by seed production date and duration of burial. Weed Res. 45: 371-378.

http://dx.doi.org/10.1111/j.1365-

3180.2005.00469.x

34. Baskin CC and Baskin JM. 1988. Germination eco-physiology of herbaceous plant species in a temperate region. American Journal of Botany. 75: 286-305.

http://dx.doi.org/10.2307/2443896

35. Teuton TC, Brecke BJ, Unruh JB, MacDonald GE, Miller GL and Ducar JT. 2004. Factors affecting seed germination of tropical signalgrass (Urochloa subquadripara). Weed Science. $\quad 25: \quad 376-381$. http://dx.doi.org/10.1614/ws-03-121r1

36. Chejara VK, Kristiansen P, Whalley RDB, Sindel BM and Nadolny C. 2008. Factors affecting germination of coolatia grass (Hyparrhenia hirta). Weed Science. 56: 543548.

http://dx.doi.org/10.1614/ws-07-163.1

37. Goettemoeller J and Ching A. 1999. Seed germination in stevia rebaudiana. In: Janicl, J. (ed). Perspectives on new crops and new uses. ASHS Press, Alexandria, VA p. 510-511.

38. Hamidi R, Mazaheri D and Rahimian H. 2009. Wild Barley (Hordeum spontaneum Koch) Seed Germination as Affected by Dry Storage Periods, Temperature Regimes, and Glumellae Characteristics. Iran. J. Weed Sci. 5(1): 1-12.

39. Saric M, Bozic D, Pavlovic D, Elezovic I and Varbnicanim S. 2012. Temperature on common cocklebur (Xanthium strumarium L.) seed germination. ROMANIAN AGRICULTURAL RESEARCH. 29: 389-393. 